\title{
Association of the Brain-derived Neurotrophic Factor Gene and Clinical Features of Bipolar Disorder in Korea
}

\author{
Hye Ji Min', Hyun-Sang $\mathrm{Cho}^{2}$, Se Joo Kim², Jeong-Ho Seok ${ }^{2}$, Eun Lee ${ }^{2}$, Duk-In Jon ${ }^{1}$ \\ Department of Psychiatry, 'Hallym University College of Medicine, Anyang, ${ }^{2}$ Yonsei University College of Medicine, Seoul, Korea
}

\begin{abstract}
Objective: Brain-derived neurotrophic factor (BDNF) plays an important role in cell survival, differentiation, and cell death as well as in neural plasticity. Recent studies have suggested that BDNF is involved in the pathogenesis of bipolar disorder. The aim of this study was to investigate the association of the genetic variations of the BDNF gene with bipolar disorder in Korea. We also studied the possible association of these genetic variants with clinical features.

Methods: The allelic and genotypic distributions of Val66Met polymorphism of the BDNF gene were analyzed using a polymerase chain reaction-based method in 184 bipolar patients and 214 controls. Analysis was performed to investigate an association of the Val66Met polymorphism of the BDNF gene and the clinical features in bipolar patients.

Results: No significant difference was found between bipolar patients and controls in the genotype and allele frequencies for the investigated BDNF polymorphism. However, the age of onset of bipolar disorder among the Val/Val (25.57), Val/Met (30.42) and Met/Met (32.45) genotype groups were significantly different $(p=0.037)$.

Conclusion: This study suggests that Val66Met polymorphisms are unlikely to contribution to the genetic predisposition to bipolar disorder as a whole. But Val66Met polymorphism may be associated with age of onset of the disorder, further studies designed to investigate the relationship in a larger population may be warranted.
\end{abstract}

KEY WORDS: Bipolar disorder; Brain-derived neurotrophic factor; Polymorphism; Age of onset.

\section{INTRODUCTION}

Brain-derived neurotrophic factor (BDNF) is involved in cell differentiation, cell survival, and cell death, ${ }^{1)}$ as well as in overall central nervous system development. ${ }^{2,3)}$ BDNF plays an important role in the maintenance of neuroplasticity and regulates neurotransmitter synthesis and synaptic activity. ${ }^{4-6)}$

There is growing evidence that BDNF is involved in the pathophysiology of bipolar disorder. It has been reported to be a target for the action of mood-stabilizing agents and antidepressants. ${ }^{7-13)}$ Chen et al. ${ }^{8)}$ reported that levels of BDNF immunoreactivity were increased in postmortem hippocampal tissue among antidepressant-treated bipolar patients compared with antidepressant-untreated bipolar patients. In animal models, chronic administration of mood stabilizers was shown to up-regulate BDNF ex-

\footnotetext{
Received: March 28, 2012 / Revised: June 15, 2012

Accepted: June 26, 2012

Address for correspondence: Duk-In Jon, MD, PhD

Department of Psychiatry, Hallym University Sacred Heart Hospital,

138, Gwanpyeong-ro, Dongan-gu, Anyang 431-746, Korea

Tel: +82-31-380-3750, Fax: +82-31-381-3753

E-mail: cogni@naver.com
}

pression levels in rat frontal cortex. ${ }^{14)}$ In addition, neuroimaging studies have demonstrated that decreased BDNF levels could explain the structural brain changes observed in bipolar patients. ${ }^{15)}$

A polymorphism that results in an amino-acid substitution of methionine for valine at codon 66 (Val66Met) of the BDNF gene may alter intracellular trafficking and regulated secretion of BDNF. ${ }^{16)}$ Two family-based studies involving relatively large samples found a significant association between this Val66Met polymorphism of BDNF and bipolar disorder. ${ }^{17,18)}$ Both studies reported overtransmission of the common Val allele to patients with bipolar disorder. In contrast, several studies have failed to confirm this association between BDNF and bipolar disorder. ${ }^{19-21)}$ In the Asian population in particular, there is no evidence for an allelic or genotypic association between Val66Met and bipolar disorders. ${ }^{22-24)}$

The Val66Met polymorphism of BDNF may not play a major role in influencing susceptibility to bipolar disorder, but it may play a role in the specific clinical bipolar phenotype. For example, it has been shown that the Val66Met polymorphism of BDNF is associated with the suicidal behaviors of bipolar patients ${ }^{25)}$ and with rapid

(c) This is an Open-Access article distributed under the terms of the Creative Commons Attribution Non-Commercial License (http://creativecommons.org/licenses/by-nc/3.0) which permits unrestricted non-commercial use, distribution, and reproduction in any medium, provided the original work is properly cited. 
cycling. ${ }^{26,27)}$ Several researchers have also studied the association between BDNF and childhood-onset bipolar disorder. ${ }^{28,29)}$

We performed this study to test whether the Val66Met polymorphism of BDNF is associated with bipolar disorder in Korean subjects. We also examined the role of this polymorphism, if any, in specific clinical features that commonly present in bipolar disorder.

\section{METHODS}

\section{Subjects}

A total of 184 Korean bipolar patients participated in this study. Patients were recruited from the Hallym University Sacred Heart Hospital, the Severance Mental Health Hospital, the Severance Hospital, and the National Health Insurance Corporation Ilsan Hospital. Diagnoses of bipolar disorder were made by a psychiatrist according to the Diagnostic and Statistical Manual of Mental Disorders, 4th edition. ${ }^{30)}$ Patients with history of seizure disorder, significant head trauma, mental retardation, or substance abuse (with the exception of alcohol abuse) were excluded from the study. The patients comprised 64 men and 120 women who were $41.5 \pm 13.6$ years old (mean \pm standard deviation). The control group comprised 214 healthy college students with no history of psychiatric disorders ( 86 men and 129 women aged $23.7 \pm 2.5$ years). All subjects provided written informed consent to participate in the study after they had received a full explanation of the aims of the study and the procedures involved. The study protocols were approved by the ethics committee of each hospital.

\section{Clinical Assessments}

We collected clinical information regarding bipolar disorder via direct interviews with individual patients and family members, and from medical records. Clinical features including age at onset, polarity at onset, any psychiatric family history, and suicidal history were evaluated.

\section{Genotyping}

We used venipuncture to collect blood samples, and DNA was isolated using standard techniques. The genotyping was screened using a single base primer extension assay using ABI PRISM SNaPshot Multiplex kits (ABI, Foster City, CA, USA) according to the manufacturer's recommendations. Briefly, the genomic DNA flanking the single-nucleotide polymorphism (SNP) of interest was amplified using polymerase chain reaction (PCR) with forward primer 5'-TGATGACCATCCTTTTCCTT-3' and reverse primer 5'-CACTGGGAGTTCCAATGC-3' and with standard PCR reagents in a $10 \mu 1$ reaction volume containing $10 \mathrm{ng}$ of genomic DNA, $0.5 \mathrm{pM}$ of each oligonucleotide primer, $1 \mu 1$ of $10 \times \mathrm{PCR}$ buffer, $250 \mu \mathrm{M}$ dNTP ( $2.5 \mathrm{mM}$ each), and 0.25 units of i-StarTaq DNA Polymerase (5 units/ $\mu$ l; iNtRON Biotechnology, Seongnam, Korea). The PCR reactions were carried out as follows: 1 cycle of $10 \mathrm{~min}$ at $95^{\circ} \mathrm{C} ; 35$ cycles of $95^{\circ} \mathrm{C}$ for $30 \mathrm{sec}$, $55^{\circ} \mathrm{C}$ for $1 \mathrm{~min}$, and $72^{\circ} \mathrm{C}$ for $1 \mathrm{~min}$; and 1 cycle of $72^{\circ} \mathrm{C}$ for $10 \mathrm{~min}$. After amplification, the PCR products were treated with 1 unit each of shrimp alkaline phosphatase (SAP; Roche, Besel, Switzerland) and exonuclease I (USB Corporation, Cleveland, $\mathrm{OH}, \mathrm{USA}$ ) at $37^{\circ} \mathrm{C}$ for $75 \mathrm{~min}$ and $72^{\circ} \mathrm{C}$ for $15 \mathrm{~min}$ to purify the amplified products. A $1 \mu 1$ aliquot of the purified amplification products was added to a SNaPshot Multiplex Ready reaction mixture containing $0.15 \mathrm{pmol}$ of genotyping primer for the primer extension reaction. The primer extension reaction was carried out for 25 cycles of $96^{\circ} \mathrm{C}$ for $10 \mathrm{sec}, 50^{\circ} \mathrm{C}$ for $5 \mathrm{sec}$, and $60^{\circ} \mathrm{C}$ for $30 \mathrm{sec}$. The reaction products were treated with 1 unit of SAP at $37^{\circ} \mathrm{C}$ for $1 \mathrm{hr}$ and $72^{\circ} \mathrm{C}$ for $15 \mathrm{~min}$ to remove excess fluorescent dye terminators. A $1 \mu 1$ aliquot of the final reaction sample containing the extension products was added to $9 \mu 1$ of Hi-Di formamide (ABI). The mixture was then incubated at $95^{\circ} \mathrm{C}$ for $5 \mathrm{~min}$, placed on ice for 5 min, and then analyzed by electrophoresis (ABI Prism 3730 xl DNA analyzer; ABI). The data were analyzed using GeneMapper software (version 4.0; Applied Biosystems, Carlsbad, CA, USA).

\section{Statistical Analysis}

Statistical differences in the genotype distributions and allele frequency between patients and controls were tested using the chi-square test. Comparisons among BDNF Val/Met genotype groups were conducted using the chisquare test for categorical data and one-way analysis of variance for continuous variables. The level of statistical significance was set at $p<0.05$. All tests were two-tailed.

\section{RESULTS}

The demographic characteristics of the subjects are given in Table 1. The mean age and education level differed significantly between the two groups, but there was no difference in the gender distribution.

The BDNF Val66Met polymorphism genotype distributions and allele frequencies of subjects are presented in Table 2. The genotype $\left(\chi^{2}=1.33, p=0.52\right)$ and allele 
Table 1. Demographic characteristics of the subjects

\begin{tabular}{lccc}
\hline & $\begin{array}{c}\text { Bipolar patients } \\
(n=184)\end{array}$ & $\begin{array}{c}\text { Controls } \\
(n=214)\end{array}$ & $p$ value \\
\hline Age (year) & $41.51 \pm 13.56$ & $23.73 \pm 2.51$ & $<0.01^{*}$ \\
Sex (male/female) & $64 / 120$ & $83 / 129$ & $0.37^{\dagger}$ \\
Education (year) & $12.76 \pm 4.17$ & $15.53 \pm 0.95$ & $<0.01^{*}$ \\
\hline
\end{tabular}

Values are presented as mean \pm standard deviation or number. *Independent $t$-test, ${ }^{\dagger}$ chi-square test.

Table 2. BDNF Val66Met polymorphism genotype distributions and allele frequencies in bipolar patients and normal controls

\begin{tabular}{lccc}
\hline & $\begin{array}{c}\text { Bipolar patients } \\
(\mathrm{N}=184)\end{array}$ & $\begin{array}{c}\text { Controls } \\
(\mathrm{N}=214)\end{array}$ & P value* \\
\hline Val/Val & $66(35.9)$ & $73(34.1)$ & \\
Val/Met & $90(48.9)$ & $99(46.3)$ & 0.515 \\
Met/Met & $28(15.2)$ & $42(19.6)$ & \\
Val allele & $222(60.3)$ & $245(57.2)$ & 0.378 \\
Met allele & $146(39.7)$ & $183(42.8)$ & \\
\hline
\end{tabular}

Values are presented as number (\%)

${ }^{*}$ Chi-square test.

$\left(\chi^{2}=0.78, p=0.38\right)$ frequencies did not differ significantly between the bipolar patients and the normal controls. The Val66Met genotype distributions in these two groups complied with Hardy-Weinberg equilibrium.

Differences in clinical variables in the various BDNF Val66Met genotype groups are presented in Table 3. Val/Val, Val/Met, and Met/Met bipolar patient groups did not differ significantly with regard to polarity at onset, any psychiatric family history, or suicidal history. The only clinical feature that did differ significantly among the three genotype groups was age at disorder onset.

\section{DISCUSSION}

In the present study the allelic and genotypic distributions of the Val66Met polymorphism of BDNF in bipolar disorder were studied with the aim of verifying their roles in the genetic susceptibility to bipolar disorder. The results provide no support for an association between bipolar disorder and the Val66Met polymorphism of BDNF. However, we did find a significant association between this polymorphism and the age at disorder onset.

The age at the onset of bipolar disorder may be a potentially important marker of a more familial and more severe form of the disorder. ${ }^{31)}$ In agreement with our finding, it has been reported that bipolar patients with the Val/Val genotype experience an earlier onset of the illness (on average by 11 years) than those with the Val/Met genotype. ${ }^{32)}$ Similarly, Skibinska et al. ${ }^{20)}$ reported a significant association with the Val66Met polymorphism in a sub-
Table 3. Differences of clinical variables in BDNF Val66Met genotype groups

\begin{tabular}{lcccc}
\hline & $\begin{array}{c}\text { Val/Val } \\
(n=66)\end{array}$ & $\begin{array}{c}\text { Val/Met } \\
(n=90)\end{array}$ & $\begin{array}{c}\text { Met/Met } \\
(n=28)\end{array}$ & p value \\
\hline $\begin{array}{c}\text { Age at } \\
\text { onset (year) }\end{array}$ & $25.57 \pm 8.35$ & $30.42 \pm 12.91$ & $32.45 \pm 13.46$ & $0.037^{\star}$ \\
$\begin{array}{c}\text { Polarity at onset } \\
\text { Manic episode }\end{array}$ & $34(69.4)$ & $46(63.0)$ & $17(68.0)$ & \\
$\begin{array}{c}\text { Depressive } \\
\text { episode }\end{array}$ & $15(30.6)$ & $27(37.0)$ & $8(32.0)$ & \\
$\begin{array}{c}\text { Any psychiatric } \\
\text { family history }\end{array}$ & $15(30.6)$ & $21(30.0)$ & $5(21.7)$ & $0.716^{\dagger}$ \\
Suicide history & $4(7.4)$ & $10(13.0)$ & $4(16.0)$ & $0.461^{\dagger}$ \\
\hline
\end{tabular}

Values are presented as mean \pm standard deviation or number (\%). "One-way analysis of variance, ${ }^{\dagger}$ chi-square test.

group of bipolar patients with early-onset disease, but there was no association between the presence of the Val66Met polymorphism and bipolar disorder overall. In addition, a recent study performed in China demonstrated that the frequency of the Val allele in the Val66Met polymorphism was significantly increased in the subgroup of patients who were younger at the onset of bipolar disorder. $^{33)}$ Recent evidence also suggests that decreased BDNF gene expression plays a role in the pathophysiology of pediatric bipolar disorder. ${ }^{34)}$ Therefore, our results suggest that the BDNF gene may be a modifier of age at onset of bipolar disorder.

Several genetic studies have shown a significant association between the BDNF Val66Met polymorphism and several psychiatric disorders. ${ }^{35-37)}$ In patient with schizophrenia, the BDNF Val66Met polymorphism was found to be associated with age at onset. ${ }^{38)}$ The Val66Met genotype may be involved in the expression of psychiatric phenotype in psychiatric disorders by modulating the activity of many neurotransmitter systems. ${ }^{4,39,40)}$

Many studies have analyzed samples of different ethnic backgrounds; significant differences in BDNF Val66Met genotype frequency have been reported between populations from Japan, USA, and Italy. ${ }^{41)}$ There are also reports of allelic or genotypic association between Val66Met and bipolar disorder in Caucasians than in other ethnic groups, and so the BDNF gene possibly represents a prominent genetic risk factor in this ethnic group. Differences in more general genetic backgrounds or local differences in and around the BDNF gene may lead to inconsistent results in different populations.

Our study has several limitations. The first of them is the use of multiple comparisons. Although Bonferroni's correction would be more appropriate, this was not applied since this study was an explorative approach to a ge- 
netically complex trait for which the relationship between genotype and phenotype has not been established, and thus such corrections might inappropriately increase the likelihood that real effects will be missed (type II error rates). Second, we did not use structured clinical interview for normal control screening. Therefore, it might be possible that some subjects with psychiatric problems were included in control group. However, because this kind of potential misclassification usually decreases the statistical power rather than increase, the type I error in this study might not be increased. Third, our failure to find a significant association between the Val66Met polymorphism of BDNF and bipolar disorder may be due to the small sample. Fourth, there was significant difference between the mean ages of the patient and control groups. The mean age of the control group was 23.73 years, and so it is possible that some members of that group would develop bipolar disorder after the completion of our investigation, which may have affected our results. Fifth, we focused on single markers that do not cover the entire region of the BDNF gene. Two recent genome-wide association studies found that four other SNPs were significantly associated with bipolar disorder. ${ }^{42,3)}$ Finally, clinical features based on retrospective reports are subject to recall bias. However, we tried to minimize this bias by obtaining collateral information from all available medical records and from interviews with close relatives.

In conclusion, we found no association between the Val66Met polymorphism of BDNF and bipolar disorder. However, we have shown that the BDNF gene can represent a genetic risk factor for an earlier onset of bipolar disorder. Further investigations with larger samples are necessary to confirm the validity of these results. Studies designed to increase our understanding of these associations and to find new candidate genes arising from the genome-wide association studies are needed.

\section{REFERENCES}

1. Jones KR, Reichardt LF. Molecular cloning of a human gene that is a member of the nerve growth factor family. Proc Natl Acad Sci U S A 1990;87:8060-8064.

2. Hofer MM, Barde YA. Brain-derived neurotrophic factor prevents neuronal death in vivo. Nature 1988;331:261-262.

3. Hanson IM, Seawright A, van Heyningen V. The human $B D N F$ gene maps between FSHB and HVBS1 at the boundary of 11p13-p14. Genomics 1992;13:1331-1333.

4. Altar CA, Cai N, Bliven T, Juhasz M, Conner JM, Acheson $\mathrm{AL}$, et al. Anterograde transport of brain-derived neurotrophic factor and its role in the brain. Nature 1997;389:856860.

5. Bartrup JT, Moorman JM, Newberry NR. BDNF enhances neuronal growth and synaptic activity in hippocampal cell cultures. Neuroreport 1997;8:3791-3794.
6. Huang EJ, Reichardt LF. Neurotrophins: roles in neuronal development and function. Annu Rev Neurosci 2001;24:677736.

7. Nibuya M, Morinobu S, Duman RS. Regulation of BDNF and trkB $m R N A$ in rat brain by chronic electroconvulsive seizure and antidepressant drug treatments. J Neurosci 1995; 15:7539-7547.

8. Chen B, Dowlatshahi D, MacQueen GM, Wang JF, Young LT. Increased hippocampal BDNF immunoreactivity in subjects treated with antidepressant medication. Biol Psychiatry 2001;50:260-265.

9. Fukumoto T, Morinobu S, Okamoto Y, Kagaya A, Yamawaki S. Chronic lithium treatment increases the expression of brain-derived neurotrophic factor in the rat brain. Psychopharmacology (Berl) 2001;158:100-106.

10. Hashimoto R, Takei N, Shimazu K, Christ L, Lu B, Chuang DM. Lithium induces brain-derived neurotrophic factor and activates TrkB in rodent cortical neurons: an essential step for neuroprotection against glutamate excitotoxicity. Neuropharmacology 2002;43:1173-1179.

11. Shimizu E, Hashimoto K, Okamura N, Koike K, Komatsu N, Kumakiri C, et al. Alterations of serum levels of brain- derived neurotrophic factor (BDNF) in depressed patients with or without antidepressants. Biol Psychiatry 2003;54:70-75.

12. Gonul AS, Akdeniz F, Taneli F, Donat O, Eker C, Vahip S. Effect of treatment on serum brain-derived neurotrophic factor levels in depressed patients. Eur Arch Psychiatry Clin Neurosci 2005;255:381-386.

13. Karege F, Vaudan G, Schwald M, Perroud N, La Harpe R. Neurotrophin levels in postmortem brains of suicide victims and the effects of antemortem diagnosis and psychotropic drugs. Brain Res Mol Brain Res 2005;136:29-37.

14. Chang YC, Rapoport SI, Rao JS. Chronic administration of mood stabilizers upregulates BDNF and bcl-2 expression levels in rat frontal cortex. Neurochem Res 2009;34:536541.

15. Sheline YI, Gado MH, Kraemer HC. Untreated depression and hippocampal volume loss. Am J Psychiatry 2003;160: 1516-1518.

16. Egan MF, Kojima M, Callicott JH, Goldberg TE, Kolachana $\mathrm{BS}$, Bertolino A, et al. The BDNF val66met polymorphism affects activity-dependent secretion of BDNF and human memory and hippocampal function. Cell 2003;112:257-269.

17. Neves-Pereira M, Mundo E, Muglia P, King N, Macciardi $\mathrm{F}$, Kennedy JL. The brain-derived neurotrophic factor gene confers susceptibility to bipolar disorder: evidence from a family-based association study. Am J Hum Genet 2002;71: 651-655.

18. Sklar P, Gabriel SB, McInnis MG, Bennett P, Lim YM, Tsan G, et al. Family-based association study of 76 candidate genes in bipolar disorder: BDNF is a potential risk locus. Brain-derived neutrophic factor. Mol Psychiatry 2002; 7:579-593

19. Oswald P, Del-Favero J, Massat I, Souery D, Claes S, Van Broeckhoven $\mathrm{C}$, et al. Non-replication of the brain-derived neurotrophic factor (BDNF) association in bipolar affective disorder: a Belgian patient-control study. Am J Med Genet B Neuropsychiatr Genet 2004;129B:34-35.

20. Skibinska M, Hauser J, Czerski PM, Leszczynska-Rodziewicz A, Kosmowska M, Kapelski P, et al. Association analysis of brain-derived neurotrophic factor (BDNF) gene Val66Met polymorphism in schizophrenia and bipolar affective disorder. World J Biol Psychiatry 2004;5:215-220.

21. Neves-Pereira M, Cheung JK, Pasdar A, Zhang F, Breen G, Yates $\mathrm{P}$, et al. BDNF gene is a risk factor for schizophrenia 
in a Scottish population. Mol Psychiatry 2005;10:208-212.

22. Hong CJ, Huo SJ, Yen FC, Tung CL, Pan GM, Tsai SJ. Association study of a brain-derived neurotrophic-factor genetic polymorphism and mood disorders, age of onset and suicidal behavior. Neuropsychobiology 2003;48:186-189.

23. Nakata $K$, Ujike H, Sakai A, Uchida N, Nomura A, Imamura $\mathrm{T}$, et al. Association study of the brain-derived neurotrophic factor (BDNF) gene with bipolar disorder. Neurosci Lett 2003;337:17-20.

24. Kunugi H, Iijima Y, Tatsumi M, Yoshida M, Hashimoto R, Kato $\mathrm{T}$, et al. No association between the Val66Met polymorphism of the brain-derived neurotrophic factor gene and bipolar disorder in a Japanese population: a multicenter study. Biol Psychiatry 2004;56:376-378.

25. Kim B, Kim CY, Hong JP, Kim SY, Lee C, Joo YH. Brain-derived neurotrophic factor Val/Met polymorphism and bipolar disorder. Association of the Met allele with suicidal behavior of bipolar patients. Neuropsychobiology 2008;58:97-103.

26. Green EK, Raybould R, Macgregor S, Hyde S, Young AH, O'Donovan MC, et al. Genetic variation of brain-derived neurotrophic factor $(B D N F)$ in bipolar disorder: case-control study of over 3000 individuals from the UK. Br J Psychiatry 2006;188:21-25.

27. Müller DJ, de Luca V, Sicard T, King N, Strauss J, Kennedy $\mathrm{JL}$. Brain-derived neurotrophic factor $(B D N F)$ gene and rapid-cycling bipolar disorder: family-based association study. Br J Psychiatry 2006;189:317-323.

28. Geller B, Badner JA, Tillman R, Christian SL, Bolhofner K, Cook EH Jr. Linkage disequilibrium of the brain-derived neurotrophic factor Val66Met polymorphism in children with a prepubertal and early adolescent bipolar disorder phenotype. Am J Psychiatry 2004;161:1698-1700.

29. Strauss J, Barr CL, George CJ, King N, Shaikh S, Devlin $\mathrm{B}$, et al. Association study of brain-derived neurotrophic factor in adults with a history of childhood onset mood disorder. Am J Med Genet B Neuropsychiatr Genet 2004; 131B:16-19.

30. American Psychiatric Association. Diagnostic and Statistical Manual of Mental Disorders, 4th ed. Washington, DC: American Psychiatric Association; 1994.

31. Carlson GA. Bipolar affective disorders in childhood and adolescence. In: Cantwell DP, Carlson GA, editors. Affective disorder in childhood and adolescence: An update. New York: Spectrum Publication;1983. p.61-83.

32. Rybakowski JK, Borkowska A, Czerski PM, Skibińska M, Hauser J. Polymorphism of the brain-derived neurotrophic factor gene and performance on a cognitive prefrontal test in bipolar patients. Bipolar Disord 2003;5:468-472.

33. Tang J, Xiao L, Shu C, Wang G, Liu Z, Wang X, et al. Association of the brain-derived neurotrophic factor gene and bipolar disorder with early age of onset in mainland China. Neurosci Lett 2008;433:98-102.

34. Pandey GN, Rizavi HS, Dwivedi Y, Pavuluri MN. Brainderived neurotrophic factor gene expression in pediatric bipolar disorder: effects of treatment and clinical response. $J$ Am Acad Child Adolesc Psychiatry 2008;47:1077-1085.

35. Hall D, Dhilla A, Charalambous A, Gogos JA, Karayiorgou M. Sequence variants of the brain-derived neurotrophic factor (BDNF) gene are strongly associated with obsessivecompulsive disorder. Am J Hum Genet 2003;73:370-376.

36. Ribasés M, Gratacòs M, Armengol L, de Cid R, Badía A, Jiménez L, et al. Met66 in the brain-derived neurotrophic factor (BDNF) precursor is associated with anorexia nervosa restrictive type. Mol Psychiatry 2003;8:745-751.

37. Rosa A, Cuesta MJ, Fatjó-Vilas M, Peralta V, Zarzuela A, Fañanás L. The Val66Met polymorphism of the brain-derived neurotrophic factor gene is associated with risk for psychosis: evidence from a family-based association study. Am J Med Genet B Neuropsychiatr Genet 2006;141B:135-138.

38. Numata $S$, Ueno S, Iga J, Yamauchi K, Hongwei S, Ohta K, et al. Brain-derived neurotrophic factor (BDNF) Val66Met polymorphism in schizophrenia is associated with age at onset and symptoms. Neurosci Lett 2006;401:1-5.

39. Hyman C, Hofer M, Barde YA, Juhasz M, Yancopoulos GD, Squinto SP, et al. BDNF is a neurotrophic factor for dopaminergic neurons of the substantia nigra. Nature 1991;350: 230-232.

40. Mössner R, Daniel S, Albert D, Heils A, Okladnova O, Schmitt A, et al. Serotonin transporter function is modulated by brain-derived neurotrophic factor (BDNF) but not nerve growth factor (NGF). Neurochem Int 2000;36:197-202.

41. Shimizu E, Hashimoto $\mathrm{K}$, Iyo M. Ethnic difference of the BDNF 196G/A (val66met) polymorphism frequencies: the possibility to explain ethnic mental traits. Am J Med Genet B Neuropsychiatr Genet 2004;126B:122-123.

42. Wellcome Trust Case Control Consortium. Genome-wide association study of 14,000 cases of seven common diseases and 3,000 shared controls. Nature 2007;447:661-578.

43. Baum AE, Akula N, Cabanero M, Cardona I, Corona W, Klemens B, et al. A genome-wide association study implicates diacylglycerol kinase eta $(D G K H)$ and several other genes in the etiology of bipolar disorder. Mol Psychiatry 2008;13:197-207. 